Published as: Van de Walle, S. \& Scott, Z. (2011). 'The political role of service delivery in statebuilding: Exploring the relevance of European history for developing countries". Development Policy Review, 29(1): 5-21

\title{
The Political Role of Service Delivery in State- Building: Exploring the Relevance of European History for Developing Countries
}

\author{
Steven Van de Walle \& Zoe Scott
}

Concerns about failed and fragile states have put state- and nationbuilding firmly on the academic and policy agenda, but the crucial role of public services in this process has remained underexplored. The 1960s and '70s generated a substantial set of literature that is largely missing from current writing. It identified state penetration, standardisation, and accommodation as key processes in the state- and nation-building sequence. This article analyses these three processes in Western Europe in the seventeenth to nineteenth centuries, and the role of public services therein, to explore how they may help us to understand the success and failure of state- and nation-building in developing countries and fragile states.

Key words: State-building, nation-building, fragile states, public-service delivery, state penetration, accommodation, standardised services

\section{A renewed interest in state- and nation-building}

Any cursory review of recent publications in the fields of development, politics or international relations will confirm that 'state-building' has experienced a sustained renaissance of interest since the early 2000s (Dobbins et al., 2003; Fukuyama, 2004; Šelo Šabić, 2005; Ottaway, 2002; Rondinelli and Montgomery, 2005; Lister and Wilder, 2005; Etzioni, 2004; Berger and Weber, 2006; Hopp and Kloke-Lesche, 2005, Whaites, 2008; Rocha Menocal, 2010). It is the primary topic of several recent books, journal symposia and research initiatives, with an even larger literature that relates implicitly to the topic.

This renewed interest follows shifts in the literature and in practice in the 1990s towards a 'rediscovery' of the role of institutions and the state for development and democracy (Evans et al., 1985; North, 1990) after a decade of focusing on reducing the role of the state and unleashing the market (Fukuyama, 2004). Effective institutions came to be seen as prerequisites for building a functioning democracy (Wang, 2003: 41 ), and good governance made its entry in the development discourse. As international donors have increasingly focused their attention on fragile states, the concept of 'state- 
building' has become mainstream in development practice and researchers have ncreasingly emphasised the importance of legitimate effective public institutions for development (Brinkerhoff and Brinkerhoff, 2002; Brinkerhoff, 2005). In this article we focus primarily on fragile states, purely because that is the context in which the statebuilding agenda has risen in importance amongst development policy-makers. However, we also recognise that the article is relevant to other development contexts.

As part of state-building strategies, international donors are increasingly focusing on strengthening state public services in recipient countries. In earlier decades, they had tended to avoid the state in their efforts to provide public services such as health, education, sanitation, etc. to the poor, and instead relied on provision through markets, non-profit organisations, NGOs and other types of voluntary organisations. Recently, however, they have begun to investigate whether such strategies, geared towards efficient and effective public-service delivery, may affect state capacity and citizens' identification with the state (OECD, 2008a, b; Batley and McLoughlin, 2010). ${ }^{1}$ Research on state-building from the early and mid-2000s tended to overlook the role of public-service provision, instead concentrating on governance dimensions such as democratisation and elections (Waldman, 2007; Wang, 2003). If services were addressed, research tended to focus on centralised activities rather than decentralised delivery, and on the 'how' of delivering services in weak or fragile states (for example, strategies for coping with weak infrastructure or sequencing interventions) rather than 'why' public services may be important for state-building. Service-delivery goals in fragile states were generally viewed as legitimate ends in themselves, with an unquestioned assumption that improving services would generally improve state legitimacy (Waldman, 2007).

However, research in this area is constantly evolving. In the last few years, understanding has shifted to a much more politically nuanced concept of state-building. The OECD now defines it as 'action to develop the capacity, institutions and legitimacy of the state in relation to an effective political process for negotiating the mutual demands between state and societal groups' (OECD 2008a). Politics has come centrestage. DFID similarly is viewing state-building through a political lens, in particular investigating the role of 'political settlements' in determining state resilience. Political settlements are defined by DFID as 'the forging of a common understanding, usually among elites, that their best interests or beliefs are served by a particular way of organising political power' (Whaites, 2008; see also Di John and Putzel, 2009). The role of services in state-building is increasingly preoccupying donors, and services are now widely viewed as having a political role to play, and as making a complex contribution to the development of state/society relations (Eldon and Gunby, 2009). This is not surprising; experts on service delivery in non-fragile contexts have long argued that service provision is a highly political undertaking (Batley, 2004; Joshi, 2006). We would underscore this point, emphasising that donors cannot assume that service provision is an apolitical, non-controversial starting-point for state-building interventions. Instead, as this article will explore, the delivery of public services is an inherently political issue that has been used for political ends throughout history.

1. At the time of writing DFID is in the process of awarding several research programmes related to this topic. 


\section{Exploring European experiences}

Notwithstanding the large growth of publications on state- and nation-building, a number of high-profile examples, such as the reconstruction of the state in post-war Germany and Japan, or, more recently, Bosnia, have received disproportionate attention. Admittedly, Germany and Japan 'set a standard for post-conflict nation-building that has not since been matched' (Dobbins et al., 2003: xiii). But, much of the traditional literature on state- and nation-building is remarkably absent from the current writings that try to shed light on the situation in, for instance, Iraq or Somalia. During the 1960s and '70s, scholars devoted considerable attention to the processes of state- and nationbuilding in Western Europe in the seventeenth to nineteenth centuries (Migdal, 2001; Eisenstadt and Rokkan, 1973; Rokkan et al., 1987; Tilly, 1975a). In Europe, the work of Stein Rokkan was central to the development of new frameworks for analysis (Flora et al., 1999), and Tilly has broadened our understanding of macro-historical processes and evolutions (Tilly, 1975a; 1992). Much of this literature also extended to developing countries because decolonisation had created a need to build new nations (Bendix, 1964; Stone, 1965).

In this article, we shall rely on a number of key concepts used in this European literature to reflect on the importance of public services in current state- and nationbuilding. We first show why it is important to distinguish between state- and nationbuilding, and how the two processes complement each other. We also show why certain terminology is being used in the international donor community. We then illustrate how public services played a role in state- and nation-building in Western Europe. More specifically, we shall describe three separate processes that have been identified by the literature: penetration, standardisation, and accommodation. Subsequently, we discuss the implications of these findings for current state- and nation-building in developing countries and fragile states. We end by formulating a number of challenges for contemporary state- and nation-builders.

\section{State- vs. nation-building}

There is much confusion over the terms 'state-building' and 'nation-building' (Hippler, 2004; Goldsmith, 2007). Historically, in a Western European context, the terms refer to different periods in time. State-building refers to processes in seventeenth- and eighteenth-century Europe, when many of the contemporary states started to consolidate, requiring the further development of modern bureaucracies (Tilly, 1975a). Nation-building mainly refers to nineteenth-century processes further contributing to the psychological integration of states. In nation-building, states reached out to the masses, and public services have been an important instrument in this. The nineteenth century saw the emergence of conscription, obligatory schooling, as well as an improved communications and infrastructure network through new roads, railways, and postal services (Weber, 1976). These 'agencies of change' (ibid.: 193) completed the process of state-building, and contributed to the development of a nation.

In current development literature, most people use 'state-building' to refer to interventionist strategies to restore and rebuild the institutions and apparatus of the state, for example the bureaucracy. In contrast, 'nation-building' also refers to the creation of 
a cultural identity that relates to the particular territory of the state. In current approaches to state-building in developing countries and failed states, the focus is on making governance effective (Rondinelli and Montgomery, 2005). The literature generally neglects the 'building a cultural identity' aspects of nation-building, choosing instead to focus on the more technical aspects of building state capacity. Writers might therefore claim to be writing about nation-building, but in fact their emphasis is really on state-building. Indeed, recent work from the field of development studies almost exclusively uses the term 'state-building'.

There are historical reasons why external actors engaged in state-building activities might be cautious about their choice of terminology. Whilst state-building and nation-building are often used interchangeably in current debates outside the field of development studies, they have not always been perceived as synonymous. Nationbuilding was heavily discussed in the literature of the 1950s and 1960s and carried a strong conceptual link to modernisation theories of development (Dinnen, 2006; Hippler, 2005?). During the Cold War, the US and the USSR both used 'nationbuilding' as a tactic to limit the reach of their enemy. However, by the 1970s the term fell out of favour, having been linked with the US's involvement in the Vietnam war. The recent willingness to discuss state-building in terms of 'neo-imperialism' or 'neocolonialism' (Mallaby, 2002; Paris, 2006; Etzioni, 2004) has led parts of the development community to distance themselves from this terminology for fear of being accused of 'neo-colonialist' activities.

However, although 'state-building' is possibly a less controversial term than 'nation-building' for external actors to use to describe their interventions, there has, in recent years, been a tendency for the difference between the two terms to become less marked and for them to be used interchangeably by many in the international community. This is most common in non-academic, non-development-related circles, and has probably been influenced largely by the tendency of the former Bush Administration (and, as a result, the media) to use the term 'nation-building' for its interventions in Afghanistan and Iraq. As a result, it is increasingly being used for activities that could more accurately be described as 'state-building'.

A further issue contributing to the confusion is that the development community has debated the extent to which all development activities can be categorised as stateand nation-building (Mallaby, 2002). Many aspects of mainstream development activity such as those focusing on good governance or anti-corruption and the increasing focus of development policy on politics and the state are actually state-building activities, albeit not explicitly labelled in that way. In general, despite the now widespread use of the term, development experts have been slow to adopt the language of state-building. This may be an attempt to distance themselves from the modernisation theories of the past and the aggressive foreign policies of the present, or it may be in recognition of what an extremely large and diverse topic state-building really is - development practitioners generally tending to specialise in aspects of building state capacity rather than claiming expertise in how to develop all aspects of a nation-state. Hence their tendency is to focus on specific aspects (for example, service-delivery measures, tax reforms, civil-service reform, infrastructure development, democratisation, political party support, public financial management training, civil-society support, peacebuilding and conflict management) rather than tackling 'state-building' as one coherent concept. 


\section{The role of public services in European nation-building: Key processes and implications}

Public services are what makes the state visible to its citizens - citizens' direct line to government. They make the state tangible through an almost daily interaction, direct or indirect. States are shaped by images and practices (Migdal, 2001: 16), and public services contribute to their creation. Standardised and relatively centralised public services have played a pivotal role in state- and nation-building in Western Europe (Barker, 1944). While the state or the ruling powers had been visible for a long time through several types of 'public services', such as tax collection, justices of the peace, conscription in the army, etc., major changes happened when (modern) states started to consolidate. Several processes in nineteenth-century European state- and nationbuilding contributed to this increase in visibility: post offices, town halls, police posts, hospitals, schools, etc. were built in many localities; people were hired and paid as police officers, village teachers, railway station masters, town hall clerks, etc. thereby creating a sense of loyalty and belonging to the state; public infrastructure works made the previously distant centres of power more accessible (Weber, 1976).

Territorial consolidation is one of the key characteristics of the development of the modern state (Finer, 1975: 87). An entirely decentralised approach to public services would make the state wither away and become invisible (Paddison, 1983: 29; Fesler, 1965). The development of public services was part of a process of nation-building through coercion and homogenisation (Tilly, 1975b: 43). Institutions such as obligatory schooling or mass conscription contributed to the socialisation of the population into the values of the state, while the new physical networks (railways, roads) and standardised public services such as post offices contributed to a physical and mental integration of the national territory. Public services carried and diffused the values of the new nations. These institutions and networks created a visible distinction between 'in' and 'out' and helped to establish clear territorial boundaries. This definition of boundaries also happens through small things such as changes in road markings or traffic signs, in the same way as a presence or absence of certain commercial 'brands' indicates that you have left a certain area or country. Public services in this way contribute to the bonding between the state and citizens.

Our thinking about the role of public services in state- and nation-building in fragile states and other developing countries may benefit from an analysis of processes of state- and nation-building in Western Europe. The descriptive and analytical historical literature, and the conceptual writings of Rokkan and Tilly in particular, reveal three main processes: penetration, standardisation and accommodation. Public services may contribute to the integration of peripheries and to the consolidation of a territory; they may contribute to a standardisation, thereby facilitating exchange, mobility and equity; and they may be used as a tool for power-brokering, pacification, and accommodation.

\subsection{Processes of penetration}


Penetration refers to a process of establishing the presence, authority and visibility of the state or the ruling powers. Finer defined it as 'the ability of the government to act directly upon the population by its own agents, instead of through intermediate local bigwigs' (Finer, 1999: 161). The aim of penetration is to contribute to the cohesion and legitimacy of the state through a process of political and territorial socialisation and, in Max Weber's words, to establish the 'monopoly of the legitimate use of physical force within a given territory' (Weber, 1974: 78). Public services are an important instrument in this process of 'penetration' whereby states establish efficient presence in and control of the national territory (Paddison, 1983: 9) and socialise its inhabitants (Newman, 2006; Duchacek, 1970). Michael Mann (1984) used the concept 'state infrastructural power' to refer to a variety of penetration processes strengthening the autonomous power of the state, including a division of labour, coinage, weights and measures, literacy, and communication and transport infrastructure. In nineteenth-century Europe, this process has been clearly visible through the establishment of dispersed public services and the creation of infrastructure networks. It is in this period that many states saw the building of town halls, post offices, railway stations, etc. The development and modernisation of national administrations led to the creation of a series of deconcentrated offices and services. This strengthened the presence of the centre in remote and peripheral areas, or even made it genuinely visible for the first time.

Other examples are the creation of national railway systems, which 'froze' the territorial structure of Europe (Flora et al., 1999: 157), or the building of major national roads. Eugen Weber referred to road-building in nineteenth-century France as a way of linking the centre to the periphery, and these roads could effectively be labelled 'administrative highways'(Weber, 1976: 195), facilitating the movement of troops, tax collectors, school inspectors, etc. The result, according to Weber, was a 'system built to serve the government and the cities' that, due to its highly centralised nature and resulting lack of a 'supporting network of secondary thoroughfares had little to do with popular habit or need' (ibid.). The same goes for the structure of railway systems, whose networks tend to radiate to and from the capital in centralised states.

The result of the modernisation of the state and the resulting state penetration, not only in nineteenth-century European states but also in their colonies in the midtwentieth century, was that 'Even in the most remote parts of a country, states have had a huge impact ... Remote villages have state-financed police, roads, potable water, state tax collectors, credit, marketing cooperatives, schools, subsidised contraceptives, electricity, health care, and more' (Migdal, 2001: 55). The establishment of a fieldservice apparatus greatly facilitated the execution of policies and the control over local jurisdictions (Paddison, 1983: 9).

A key process in this penetration is 'boundary-building', by which the scope and extent of the territory and the state is clearly demarcated. In its territorial sense, boundary-defining is easy to imagine. In its social meaning, the boundary separates 'the state from other non-state, or private, actors and social forces' (Migdal, 2001: 17). The latter was highly visible in European struggles for hegemony between the secular state and the Church (Gill, 2003). In a situation with mixed state and non-state provision of public services, and especially in situations where geographical boundaries are unclear, disputed, or changing, such boundary building may be difficult (Anderson, 1991: 114), and may have an adverse effect on penetration capacity, and thus state- and nationbuilding. 
These examples show that the process of penetration is not always a harmonious and uncontested one. It is about establishing control. It is noteworthy that, in his work on state-building, Charles Tilly also used 'state-making'. It refers to a coercive process of penetration by attacking, eliminating and neutralising internal rivals (Tilly, 1992: 54; 1985: 181). This may or may not include the introduction of merit-based bureaucracies to curtail the power and privileges of other dominant groups in the organisation of public services (Jacoby, 1973: 175). The frequent use of the terms 'centre' and 'periphery' in the state- and nation-building literature implies a relation of subordination of the periphery to the centre (Gottmann, 1980: 17). It requires that the state supersedes or controls alternative sources of authority, or those that are or could become challenges to its supremacy.

\subsection{Processes of standardisation}

A second key process, different from but related to penetration, is standardisation, namely, a process of establishing a standard, in this case an administrative or servicedelivery standard that applies to the entire polity. Standardisation and centralisation generally move in pairs. The establishment of royal bureaucracies and of systems of tax collection and justices of the peace in the feudal and early modern states is the first example. Later evolutions showed central royal power growing with the expansion of national bureaucracies. This combination of centralisation and standardisation is perhaps best visible in the legal and administrative reforms initiated by Napoleon, or earlier in the acts of enlightened despots such as the Habsburg Maria Theresa and her son Joseph II who had a weakness for administrative uniformity (Scott, 1990).

In later stages, standardisation is expressed through similar administrative procedures for all citizens: the use of identification documents (Torpey, 2000); a statistical system for the classification of citizens, groups, and territories (Scott, 1998); integrated curricula for schools (Gellner, 1983: 52); networks of post offices; uniforms for certain public-sector staff; national television (Dhoest, 2007); a common architecture for public buildings; etc. In many cases encounters between citizens and administrations and public institutions such as schools or the army (conscription) also contributed to the creation of a common language. Standardisation, as exercised through public services, contributed to the creation of a common culture through the presence of similar and readily identifiable public services. Riggs speaks in this context about state nationalism (Riggs, 1997: 351), where a state creates a nation. Public services diffuse cultural symbols of statehood and nationhood (Shils, 1975: 39). They are symbols of state presence. Through a process of homogenisation (Tilly, 1975a), this standardisation attempts to build a moral unity (Wang, 2003: 37). The state, using its services, builds an imagined community (Anderson, 1991); it manufactures and nourishes imagery, and it communicates a package of ideals (Price, 1995: 46).

A bureaucracy is a means to control diverging tendencies in autonomous bodies, agencies and organisations, and thus to integrate them (Poggi, 1990: 31-2). Standardisation may therefore require the annihilation or suppression of alternative autonomous power centres or delivery mechanisms (for example, through local strong men) that compete for people's loyalty and identity (Wang, 2003). This may even mean changing, dismantling or neutralising well-functioning service-delivery mechanisms (Braun, 1975). It may also lead to the suppression of diverging identities (the former 
French centralist approach geared towards the suppression of regional languages is a good example). This standardisation aids identification with the state, and, by doing so, also attempts to break down identification with alternative authorities (such as other states, regional or local interests, or competing leaders). The processes of modernisation with which nineteenth-century European state-building is associated are characterised by a certain degree of 'enforced uniformity' (Poggi, 1990: 81). This extends to those employed in public services. It is insufficient that someone performs his/her duty in delivering a service. He/she also needs to identify with a wider state apparatus and show solidarity and connection with fellow public-sector workers. Such a process of standardisation is probably relatively straightforward in a context of rapid modernisation when many of the public services are new rather than replacing existing ones. It may be much more damaging in a context where efficient alternative servicedelivery mechanisms already exist.

\subsection{Processes of accommodation}

Accommodation refers to processes of reconciliation or settlement, generally between elites. Adding it to our list of processes helps to explain why processes of penetration and standardisation have actually worked and have encountered less resistance than one might expect. Public services may serve as instruments for dispute settlement and for the creation of political loyalty. Despite what NPM-style literature may lead us to believe, public services and public servants do more than delivering undisputed services in a neutral manner.

The vast scholarship on the role of politics, political appointments, spoils etc. in administrations demonstrates the extent to which the provision of public services and of positions within them is a key element in political power-brokering and accommodation. Accommodation may be a means of 'binding critical elements of the population to the state' (Migdal, 2001: 77) and act as a safeguard against the development of competing centres of power within the state (ibid.: 75). Public services are in such a case a tool to buy loyalty and to make disloyalty expensive. Working with local notables rather than imposing power has in some cases been a very effective strategy (Gill, 2003). Furthermore, by providing a clear path for social mobility, publicsector employment has contributed to social harmony and has promoted citizens' identification with the state.

In divided societies, public services may contribute to the maintenance of a delicate balance between groups. They have had, and still have in the case of developing or post-conflict countries, a role in nation- and identity-building and pacification (Stillman, 2000: 18; Thompson, 1965: 208). Sharing out public-sector jobs or a promise to provide certain facilities to certain individuals, groups or regions is an excellent instrument to cement political pacts. Such processes of accommodation are especially visible in ethnically divided societies where quota are sometimes used in the distribution of public offices (Bangura, 2006). Public administration, institutions and services may help to resolve cultural conflicts between majorities and minorities. Bourgeois speaks in this context of 'administrative consociationalism' (Bourgeois, 2007: 633), echoing Lijphart's concept which has largely been applied to political structures at the central level (Lijphart, 1977), rather than to a more decentralised level of public-service delivery such as schools and local public services. This shows that a 
distribution of resources in the modern state should not just be approached from an equity perspective, but that there is also a strong instrumental dimension to redistribution (Wang, 2003).

Accommodation and dispute settlement may require some decisions which may not always be well-received and may be criticised for their lack of democratic character. These processes of accommodation reveal an interesting paradox in state- and nationbuilding initiatives, especially when these initiatives also aim to promote democratisation. Elite pacts, including arrangements on public-service delivery, in a way attempt to achieve the principles of the modern democratic state by using methods that would not generally be associated with such a polity. O'Donnell and Schmitter made a similar point when they introduced the concept of elite pacts into the politicalscience literature through their study on transitions from authoritarianism in Latin America: 'Ironically, such modern pacts move the polity toward democracy by undemocratic means' (O’Donnell and Schmitter, 1986: 38).

The opposite case, however, while based on a similar principle, generally attracts much less criticism. We have seen several instances where certain groups have been removed from administrative and public-service positions precisely for their lack of loyalty to, or even betrayal of, the polity. This tends to happen in times of change and of challenged power. Good examples are the lustration processes in several Central and Eastern European post-communist societies, especially in Czechoslovakia; denazification in post-war Germany; or more recently de-Baathification in Iraq (David, 2006; Ellis, 1996). Yet, for the sake of completeness it needs to be mentioned that public services are less subject to such processes than, for example, military or political bodies. Just as with other acts of accommodation or of standardisation, such lustration processes may also have an adverse impact on the ability of public services to deliver, for example because all expertise has been weeded out (Dobbins et al., 2003: 13-14).

\section{Implications for donors}

To summarise briefly, this article has argued that public-service delivery is not neutral but a highly political matter. It has demonstrated how service provision has been used in European history as a state tool for penetration (territorial consolidation and the integration of peripheries), for standardisation (homogenisation of the population and its experiences) and for accommodation (including pacification, buying loyalty and powerbrokering). So what does all this mean for international donors keen to engage in service provision and state-building interventions in developing countries? Is this European experience, and these European models and processes, relevant or transferable to a development context?

\subsection{Transferability}

Whilst some international development researchers suggest that transferable lessons can be gleaned from the European example (Moore, 2004), others strongly assert that they cannot (Herbst, 2000). These contrary perspectives seem to centre on the question of the similarity of context. The European model grew out of a feudal system, and this has been regarded as a reason why ' $[\mathrm{T}]$ he European state-building experiences will not repeat themselves in new states' (Tilly, 1975b: 81). In a feudal system, with its 
dispersed power, suppressing the local power base that could challenge the state was relatively easy. Some, for this reason, suggest that Europe may have been the special case in history, rather than the model. Another significant difference between European state-building and current state-building processes in developing countries is the involvement of many external and international actors in the latter, including multi- and bi-lateral donors, NGOs and private institutions, each with its own practices and political agendas (Zaum, 2007).

So, given that there are significant differences and similarities between the contexts, can any lessons be learned? We do not contend that lessons from European history can be lifted directly and applied unquestioningly to the diverse contexts of developing countries where state-building ventures are taking place. However, we do argue that there are some broad principles that we can take from a backward glance at history to inform current and future practice. Learning about the European examples may facilitate analysis of the situation in other countries (Flora et al., 1999; Rokkan, 1975). In this context it is of crucial importance to recognise the wide variety of statebuilding processes in European states. The French and British experiences, for example, are very different, with the former being much more centralist. In addition, single countries have not always followed the same model over time, and have combined different approaches, some more centralised, others more decentralised (Gill, 2003). However, despite the diversity of the European experience and the specificity of the European context, we argue that the evidence of the impact of services on state processes in European history is highly relevant to current state-building initiatives. The rest of the article will explore the practical implications for the international donor community.

\subsection{Donors and penetration, standardisation and accommodation}

There are several reasons, articulated below, as to why donors should pay more attention to the political aspects of service delivery in fragile states and developing countries. In many ways, service provision, if managed properly, can play a role in furthering donor agendas for state-building. For example, state governments in fragile environments often have weak or no control over large sections of their territory (Herbst, 2000:19; Lister and Wilder, 2005). Governance in these areas can alternatively be provided by warlords, strong men and patrimonialist networks or traditional tribal systems (Reno, 1998; Lister and Wilder, 2005; Jackson, 2003). In aiming to build states, donors are often keen to expand the control of the central government beyond the confines of the capital city. Therefore, the potential ability of service provision to act as a non-violent vehicle for territorial penetration is very attractive to international donors aiming to build capable states that have controlling presence, authority and visibility throughout their land.

Standardisation is a trickier concept to discuss in this context. It maps on to donor aims if it can be translated as being a process that creates equality of access to public services; all citizens gain the same level of access to similar standards of public services throughout the territory. Conflict inspired by grievance over 'horizontal inequalities' (Stewart et al., 2008) is therefore mitigated, as no single group enjoys privileged access to basic services. However, the idea that donors engaging in service provision are inherently creating a cultural identity is more contentious. In some contexts, for 
example Afghanistan, donors might be pleased to assist in the creation of a cultural identity that maps on to the governing state rather than being exclusively related to ethnic identity. However, several authors emphasise that the development of cultural identity should be an endogenous process and is not something in which external actors should meddle (Etzioni, 2004; Ottaway, 2002) An additional problem is that the development community as a whole tends to promote social inclusion and embrace cultural diversity rather than express intolerance towards it. And finally, the question remains over what to do in contexts where alternative, non-state systems of service provision already exist (Lister and Wilder, 2005).

Lastly, how does accommodation via service provision map on to donor ambitions? Whilst most donors would be delighted with the idea that service provision can be a method of dispute settlement and generate political loyalty, the concept of explicitly using service delivery as a political tool is extremely contentious. Openly using services as methods of 'power-brokering' as opposed to the more neutral idea of basing delivery design on principles of equity and equality is a highly controversial idea. Although donors have historically been reluctant to admit to the political role they play in the countries in which they work, the UK Department for International Development, for example, is increasingly considering the impact of elite pacts or 'political settlements' on facilitating developmental goals. This is an emerging area of research in the development field.

\subsection{Implications for international donors}

Three further findings of our analysis deserve discussion, and are included here as statements that international donors must seriously consider when engaging in service provision as a state-building enterprise. Donors need to be realistic about the political role that their interventions play. That means analysing their role and the way they design programmes from a political perspective and embracing that potential, rather than being unable, or afraid, to engage in discussion over the political aspects of development interventions like service delivery.

(i) Efficiency may not be the best guiding principle for the design of public services in developing countries and fragile states. This is a highly controversial statement. Donors, with their accountability to the tax-payer, are understandably reluctant to admit that state-building is anything other than a straightforward, technocratic, apolitical undertaking. Unfortunately, in reality the opposite is usually the case. Obviously, service provision must be efficient enough to not alienate the population and thereby undermine the legitimacy of the state, or provoke conflict amongst different groups (Brinkerhoff, 2005: 5; Jackson and Scott, 2007). However, the above examples from Western Europe show that there may be situations where a political decision could be made to sacrifice efficiency for the 'greater good' of furthering penetration, standardisation or accommodation. An example may be establishing more health centres than strictly necessary in a given area in order to raise the visibility of the state there or to pacify an aggrieved group who have previously felt excluded from access to basic services. A more controversial example would be buying off local elites with jobs in public services in order to ensure their loyalty to the nascent state. Early European state-building in the fifteenth and sixteenth centuries showed a need to make civil servants first loyal to the ruler, and only later efficient and impartial 
(Fischer and Lundgreen, 1975: 457). As long as the legitimacy of the state is contested, loyalty needs to be created.

(ii) State-building is not always a democratic process. Much of the state-building process is about coercion and the accommodation of certain groups or power factions, or at least it is a relatively centrally-driven process in its early stages. Processes of homogenisation, standardisation, boundary-defining and penetration are unlikely to be universally popular. The building of states in Western Europe was in some cases costly and involved 'death, suffering, loss of rights and unwilling surrender of land, goods, or labor' (Tilly, 1975b: 71). Many were forged through blood and iron (Ottaway, 2002: 16). Populations often resisted the creation of states. This was visible in tax rebellions, food riots, and resistance to conscription (ibid.).

The creation of nations required homogenisation of certain groups in society, and sometimes the destruction of existing power structures. The process was dominated by a desire for stability and security, not democracy. A second and related element, therefore, is that much of the nation- and state-building was an elite-driven process. Nationalist movements appealed to the masses, but they were very often initiated by societal elites. O'Donnell and Schmitter (1986) gave pacts between elites a central role in transitions from authoritarian rule, and consociational arrangements are in a similar way an accommodation between elites (Lijphart, 1977). We note Ottoway's observation that 'The world should not be fooled into thinking that it is possible to build states without coercion' (Ottaway, 2002: 18). Harsh compromises are often necessary, and these include military coercion and 'the recognition that democracy is not always a realistic goal' (ibid.: 16). Yet, at the same time, counter-examples in some countries show the value of gradually establishing modern central bureaucracies, with little coercion.

The observation that state-building is not always a democratic process creates important dilemmas for international donors, because it may require them to engage in practices of which they have hitherto officially disapproved. It also highlights a discrepancy between the official policy rhetoric and practices in the field, which has massive potential to become controversial in donors' home countries and parliaments.

(iii) There is a tension between supporting nation-building and contributing to nationalism. State- and nation-building and nationalism are very closely related. Nationalism does not always have a good name; a stimulation of nationalism combined with political or even ethnic accommodation strategies may be difficult or risky. Certain processes inherent to state- and nation-building such as socialisation through the school system, army, media, or public services, or processes of boundary defining, can easily slip into forms of extreme nationalism. State- and nation-building may lead to the destruction of existing identities and allegiances, and may come at a cost for certain groups that are being assimilated. Processes of political socialisation, or the instilling of desirable features in the population, may be felt as highly intrusive and invasive (Miguel, 2004: 331). Nationalist approaches to the organisation of public services may also lead to the destruction of well-functioning existing public services and public goods, to be replaced by national ones, for the sake of it. The right balance between public services that function effectively, efficiently and economically, and public services that reflect and propagate a national or a state identity, may be particularly hard to find. 
By way of a conclusion, then, this article has a number of theoretical, but also practical, implications for the donor community. First, we conclude that service provision is an inherently political process, even more so in fragile or state-building contexts. It is impossible to predict from European examples precise routes of development, but we can conclude from our analysis that service provision can play a role in enhancing or undermining state legitimacy and social cohesion. Donors must change their practices and resource allocations to reflect this. For example, service provision should no longer be pursued in fragile states as a 'quick win' or a neutral intervention. Instead, political-economy analysis should be incorporated into programme design, resulting in more politically considered, coherent and long-term approaches to service delivery. Finally, in taking this area more seriously, donors should fund further research into how services have contributed to state-building agendas in developing countries with a view to distilling 'lessons learned' into operational tools to inform policy-making and, it is to be hoped, ensure more politically astute interventions in the future.

\section{References}

Anderson, B. (1991) Imagined Communities: Reflections on the Origins and Spread of Nationalism. New York: Verso (revised edn).

Bangura, Y. (2006) Ethnic Inequalities and Public Sector Governance. Basingstoke: Palgrave.

Barker, E. (1944) The Development of Public Services in Western Europe 1660-1930. London: Oxford University Press.

Batley, R. A. (2004) 'The Politics of Service Delivery Reform', Development and Change 35 (11): 31-56.

Batley, R. A. and McLoughlin, C. (2010) 'Engagement with Non-State Service Providers in Fragile States: Reconciling State-building and Service Delivery', Development Policy Review 28 (2): 131-54.

Bendix, R. (1964) Nation-building and Citizenship: Studies of our Changing Social Order. New York: John Wiley \& Sons, Inc.

Berger, M. and Weber, H. (2006) 'Beyond State-building: Global Governance and the Crisis of the Nation-State System in the 21st Century', Third World Quarterly 27 (1): 201-08.

Bourgeois, D. (2007) 'Administrative Nationalism', Administration and Society 39 (5): $631-55$.

Braun, R. (1975) 'Taxation, Sociopolitical Structure, and State-building: Great Britain and Brandenburg Prussia' in Tilly.

Brinkerhoff, D. W. (2005) 'Rebuilding Governance in Failed States and Post-conflict Societies: Core Concepts and Cross-cutting Themes', Public Administration and Development 25: 3-15.

Brinkerhoff, D. W. and Brinkerhoff, J. M. (2002) 'Governance Reforms and Failed States: Challenges and Implications', International Review of Administrative Sciences 68: 511-31.

David, R. (2006) 'From Prague to Baghdad: Lustration Systems and their Political Effects', Government and Opposition 41 (3): 347-72. 
Dhoest, A. (2007) 'Identifying with the Nation: Viewer Memories of Flemish TV Fiction', European Journal of Cultural Studies 10 (1): 55-73.

Di John, J. and Putzel, J. (2009) Political Settlements. An Emerging Issues Research Service Paper. Birmingham: Governance and Social Development Resource Centre (GSDRC), University of Birmingham, UK (www.gsdrc.org/ docs/open/EIRS7.pdf).

Dinnen, S. (2006) 'Nation-Building'. Concepts Paper. Draft paper for AusAID.

Dobbins, J.; McGinn, J. G.; Crane, K.; Jones, S. G.; Lall, R.; Rathmell, A.; Swanger, R. and Timilsina, A. (2003) America's Role in Nation-building from Germany to Iraq. Santa Monica, CA: RAND.

Duchacek, I. D. (1970) Comparative Federalism: The Territorial Dimension of Politics. New York: Holt, Rinehart and Winston.

Eisenstadt, S. N. and Rokkan, S. (1973) Building States and Nations: Models and Data Resources, Vol. I. London: Sage Publications.

Eldon, J. and Gunby, D. (2009) 'States in Development: State-building and Service Delivery'. London: HLSP (www.hlsp.org/LinkClick.aspx?fileticket= pTubyMeHSxk\%3d\&tabid=1791\&mid=3720).

Ellis, M. S. (1996) 'Purging the Past: The Current State of Lustration Laws in the Former Communist Bloc', Law and Contemporary Problems 59 (4): 181-96.

Etzioni, A. (2004) 'A Self-restrained Approach to Nation-building by Foreign Powers', International Affairs 80 (1): 1-17.

Evans, P. B., Rueschemeyer, D. and Skocpol, T. (1985) Bringing the State Back In. Cambridge: Cambridge University Press.

Fesler, J. W. (1965) 'Approaches to the Understanding of Decentralization', The Journal of Politics 27 (3): 536-66.

Finer, S. E. (1999) The History of Government from the Earliest Times, Volume III: Empires, Monarchies and the Modern State. Oxford: Oxford University Press.

Finer, S. E. (1975) 'State- and Nation-building in Europe: The Role of the Military' in Tilly.

Fischer, W. and Lundgreen, P. (1975) 'The Recruitment and Training of Administrative and Technical Personnel' in Tilly.

Flora, P., Kuhnle, S. and Urwin, D. (1999) State Formation, Nation-building, and Mass Politics in Europe: The Theory of Stein Rokkan. Oxford: Oxford University Press.

Fukuyama, F. (2004) State Building: Governance and World Order in the Twenty-first Century. London: Profile books.

Gellner, E. (1983) Nations and Nationalism. Oxford: Basil Blackwell.

Gill, G. (2003) The Nature and Development of the Modern State. Basingstoke: Palgrave Macmillan

Goldsmith, A. (2007) 'Does Nation-building Work?' in D. Brinkerhoff (ed.), Governance in Post-Conflict Societies: Rebuilding Fragile States. New York: Routledge.

Gottmann, J. (1980) 'Confronting Centre and Periphery' in J. Gottmann (ed.), Centre and Periphery: Spatial Variation in Politics. London: Sage.

Herbst, J. (2000) States and Power in Africa: Comparative Lessons in Authority and Control. Princeton, NJ: Princeton University Press. 
Hippler, J. (ed.) (2005) Nation-building: A Key Concept for Peaceful Conflict Transformation?London: Pluto Press.

Hopp, U. and Kloke-Lesche, A. (2005) 'External Nation-building vs. Endogenous Nation-forming: A Development Policy Perspective', in Hippler.

Jackson, P. (2003) 'Warlords as Alternative Forms of Governance', Small Wars and Insurgencies 14 (2): 131-50.

Jackson, P. and Scott, Z. (2007) 'Local Government in Post-conflict Contexts', Literature review and report to UNDP and the Oslo Governance Centre.

Jacoby, H. (1973) The Bureaucratization of the World. Berkeley, CA: University of California Press.

Lijphart, A. (1977) Democracy in Plural Societies. New Haven, CT: Yale University Press.

Lister, S. and Wilder, A. (2005) 'Strengthening Subnational Administration in Afghanistan: Technical Reform or State-building?', Public Administration and Development 25: 39-48.

Mallaby, S. (2002) 'The Reluctant Imperialist: Terrorism, Failed States and the Case for American Empire', Foreign Affairs 81 (2): 2-7.

Mann, M. (1984) 'The Autonomous Power of the State: Its Origins, Mechanisms and Results', Archives européennes de sociologie 25: 185-213.

Migdal, J. S. (2001) State in Society: Studying How States and Societies Transform and Constitute One Another. Cambridge: Cambridge University Press.

Miguel, E. (2004) 'Tribe or Nation? Nation Building and Public Goods in Kenya Versus Tanzania', World Politics 56: 327-62.

Moore, M. (2004) 'Revenues, State Formation and the Quality of Governance in Developing Countries', International Political Science Review 25 (3): 297-319.

Newman, D. (2006) 'The Resilience of Territorial Conflict in an Era of Globalization', in M. Kahler and B. F. Walter (eds), Territoriality and Conflict in an Era of Globalization. Cambridge: Cambridge University Press.

North, D. C. (1990) Institutions, Institutional Change, and Economic Performance. Cambridge: Cambridge University Press.

O'Donnell, G. and Schmitter, P. C. (1986) Transitions From Authoritarian Rule: Tentative Conclusions About Uncertain Democracies. Baltimore, MD: Johns Hopkins University Press.

OECD (2008a) Concepts and Dilemmas of State-building in Fragile States: From Fragility to Resilience. OECD / DAC Discussion Paper. Paris: OECD.

OECD (2008b) Service Delivery in Fragile Situations: Key Concepts, Findings and Lessons. Paris: OECD.

Ottaway, M. (2002) 'Nation Building', Foreign Policy 132: 16-24.

Paddison, R. (1983) The Fragmented State: The Political Geography of Power. Oxford: Basil Blackwell.

Paris, R. (2006) Understanding the 'Co-ordination Problem' in Post-war Statebuilding. RPPS Working Paper. Research Partnership on Post-War Statebuilding.

Poggi, G. (1990) The State: Its Nature, Development, and Prospects. Cambridge: Polity Press.

Price, M. E. (1995) Television, the Public Sphere and National Identity. Oxford: Clarendon Press. 
Reno, W. (1998) Warlord Politics and African States. Boulder, CO: Lynne Rienner.

Riggs, F. W. (1997) 'Modernity and Bureaucracy', Public Administration Review 57 (4): $347-53$.

Rocha Menocal, A. (2010) State-building for Peace - A New Paradigm for International Engagement in Post-Conflict Fragile States? EUI Working Papers RSCAS 2010 / 34. San Domenico di Fiesole, Italy: Robert Schuman Centre for Advanced Studies European Report on Development (http://cadmus.eui.eu/dspace/ bitstream/1814/13716/1/RSCAS_2010_34.pdf).

Rokkan, S. (1975) 'Dimensions of State Formation and Nation-building: A Possible Paradigm for Research on Variations within Europe', in Tilly.

Rokkan, S.; Urwin, D.; Aarebrot, F. H.; Malaba, P. and Sande, T. (1987) Centreperiphery Structures in Europe: An ISSC Workbook in Comparative Analysis. Frankfurt: Campus Verlag.

Rondinelli, D. A. and Montgomery, J. D. (2005) 'Regime Change and Nation Building: Can Donors Restore Governance in Post-conflict States?', Public Administration and Development 25: 15-23.

Scott, H. M. (1990) 'Reform in the Habsburg Monarchy, 1740-1790', in H. M. Scott (ed.), Enlightened Absolutism: Reform and Reformers in Later Eighteenthcentury Europe. Basingstoke: Macmillan.

Scott, J. C. (1998) Seeing Like a State: How Certain Schemes to Improve the Human Condition have Failed. New Haven, CT: Yale University Press.

Šelo Šabić, S. (2005) State Building under Foreign Supervision: Intervention in BosniaHerzegovina 1996-2003. Vienna: Bureau for Security Policy, Austrian Ministry of Defence and National Defence Academy, and Zagreb: Institute for International Relations.

Shils, E. (1975) Center and Periphery: Essays in Macrosociology. Chicago, IL: University of Chicago Press.

Stewart, F., Brown, G. K. and Langer, A. (2008) 'Policies Towards Horizontal Inequalities', in F. Stewart (ed.), Horizontal Inequalities and Conflict: Understanding Group Violence in Multiethnic Societies. Basingstoke: Palgrave Macmillan.

Stillman, R. J. I. (2000) Public Administration: Concepts and Cases. 7th edn. Boston, MA: Houghton Mifflin Company.

Stone, D. C. (1965) 'Public Administration and Nation-building', in C. M. Roscoe (ed.), Public Administration and Democracy: Essays in Honor of Paul H. Appleby. Syracuse, NY: Syracuse University Press.

Thompson, V. A. (1965) 'Bureaucracy in a Democratic Society', in C. M. Roscoe (ed.), Public Administration and Democracy: Essays in Honor of Paul H. Appleby. Syracuse, NY Syracuse University Press.

Tilly, C. (1992) Coercion, Capital and European States, AD 990-1992. Oxford: Blackwell.

Tilly, C. (1985) 'War Making and State Making as Organized Crime', in Evans et al..

Tilly, C. (1975a) The Formation of National States in Western Europe. Princeton, NJ: Princeton University Press.

Tilly, C. (1975b) 'Reflections on the History of European State-making', in Tilly.

Torpey, J. (2000) The Invention of the Passport: Surveillance, Citizenship and the State. 
Cambridge: Cambridge University Press.

Waldman, R. (2007) Health Programming for Rebuilding States: A Briefing Paper. BASICS project. Washington, DC: USAID.

Wang, S. (2003) 'The Problem of State Weakness', Journal of Democracy 14 (1): 3642.

Weber, E. (1976) Peasants into Frenchmen: The Modernization of Rural France, 18701914. Stanford, CA: Stanford University Press.

Weber, M. (1974) 'Politics as a Vocation', in H. H. Gerth and C. Wright Mills. (translators and eds), From Max Weber: Essays in Sociology. London and Boston, MA: Routledge and Kegan Paul.

Whaites A. (2008) States in Development: Understanding State-building. London: DFID.

Zaum, D. (2007) The Sovereignty Paradox: The Norms and Politics of International State-building. Oxford: Oxford University Press. 